\title{
Race-to-the-Top Strategy Paradigm
}

\author{
Alejandro Ruelas-Gossi, University of Miami, USA
}

\section{Introduction}

This article proposes a novel approach to business strategies and public policies toward bridging the gap between developed and emerging economies. A race-to-the-top paradigm, based on the sophistication (value enhancement) of resources that are distinctively present across every region in the planet is proposed. This approach introduces a virtuous circle by leveraging a country's natural advantage through a value-enhancing sophistication strategy toward a self-perpetuating virtuous circle of development. Leveraging those resources may potentially attain high levels of sophistication, and accordingly, of higher per capita income/value for the region/nation. A development strategy based on value-enhancement is superior to a strategy based on mere cost reduction. Examples from New Zealand, the Basque Country (Spain), and Chile are presented. A number of implications for business strategy as well as for public policy are discussed, and a framework for this new paradigm based on five patterns is explained in the article.

The widespread paradigm among policymakers and academics that study the process of how developing countries catch-up with developed countries (Ghemawat \& Altman, 2016; Ruelas-Gossi, 2004) is that, essentially, the way forward for developing countries is to integrate into the global value chains, mostly by carrying out low value-added activities within the chain (Ruelas-Gossi \& Sull, 2006). Accordingly, we have witnessed development strategies that are focused on reducing costs based on the exploitation of natural resources with lower potential for added value (extractive and agricultural sectors), assembly process (à la Maquila Industry), and low value-added services (such as call-centers) (Ruelas-Gossi, 2004, 2010a).

\section{Traditional Paradigm}

For almost five decades, countries in Latin America, particularly Mexico (and other countries in Central America), have welcomed foreign assembly plants and factories, known as maquiladoras. Let us consider a real example (from McClatchyDC): Sergio Martinez, a worker in a maquiladora, PKC. His salary has been the same for more than a decade ( $\$ 7.50$ a day). Sergio is part of the millions of workers who can only dream of buying the appliances, or the cars they help manufacture. He and his family live like poor dirt farmers, in what Mexicans call a jacal (a homemade shanty of scrap wood and tarpaper). These poor living standards are not just emblematic of the industrial sector of Mexico-a human cog in a global supply chain — but also a magnet for foreign investment. The poverty traps them with the same salary for years. The government tries to compensate with subsidizing credit, to purchase appliances or even simple houses, sinking them into debt. Their children rather than staying in school, will end up going to factories like their parents, or worse, will join criminal gangs.

Mexico is not the exception, but the rule. And this race-to-thebottom paradigm of keeping low salaries can be even worse (Kay \& Lewenstein, 2013). The non-written rule is to comply with what we call the metrics of the poverty trap: lowest cost, best quality and delivering on time. When those are not met, a more drastic event occurs. After almost 20 years in Costa Rica, Intel cut 1,500 jobs and relocated them to Asia in 2014. Both outcomes of the current paradigm are undesirable: the poverty trap and the sudden loss of jobs, fostering a vicious circle of low-cost activities that fail to accumulate the skills for sustained long-term growth. Costa Rica surrogates itself to externally-generated knowledge, jobs with enslaving conditions and effectively becomes a remora of developed countries, making the country more exposed to the volatility of foreign direct investment (FDI).

\section{The New Top Strattegy"s Paradigm}

For nearly a decade, I have pointed to the perils of a maquiladora-dependent-economic-model for emerging economies (Ruelas-Gossi, 2010a, 2010b) because it is deeply flawed, but 
since there was for decades an "alternative" (the easy one), it became the preferred path of choice. Nobody questioned that the forces of globalization with its off-shoring practices (arbitrage) were an integral part of the global-supply-chains.

The geoeconomic world was then divided, into the world of thinking and the world of doing. Year by year this division got more acute. The thinking jobs remained in the developed economies. The doing jobs were transferred to developing economies, dragging them into the metrics of poverty, mentioned above.

The Long Global Great Recession-as well as the advanced-manufacturing (robots) - has provoked a drastic loss of jobs in developed economies, and in looking for someone to blame, some developed economies found in trade-agreements a suitable scapegoat. The resurgence of protectionism is being pervasive in both Brexit and Trump campaigns. It is becoming the new-normal argument for keeping jobs inside.

The model proposed here offers a new avenue of interaction that avoids the zero-sum game of the traditional off-shoring arbitrage practices. The race-to-the-top strategy paradigm provides a fresh thinking-thinking paradigm. It is based on the sophistication (value enhancement) of resources that are present (natural) in a given country. This approach introduces a virtuous circle by leveraging a country's natural advantage through a value-enhancing sophistication strategy toward a self-perpetuating virtuous circle of development. It requires a drastic rethink of the role of FDI from MNCs in economic development for an emerging country. Rather than serving to create low-paid jobs, FDI would be drawn to a country to enhance and develop its economic potential through the construction of value in the society.

This redefinition entails an enormous shift in relations between MNCs and emerging markets. For emerging economies, this model offers the chance to develop in a more sustainable way that is more advantageous to the broader population. However, to realize this, the emerging economies need the sophisticated knowledge of a developed market counterpart. In the long term, this model offers better economic conditions in a foreign market for an MNC through customers with more buying power.

Promoting genuinely sustainable economic development between an emerging economy and MNCs would help stem the mass exodus of people fleeing the troubled regions of the Middle East and Africa for the more stable regions of Europe. For instance, if emerging economies began to enjoy the benefits of economic specialization and sophistication, fewer people would be motivated to move elsewhere. Therefore, this new strategic perspective could generate a solution for political and social problems from migration movements.
On the other hand, the beggar-thy-neighbor forms of trade that became popular with the explosion of global trade in the 1990 s, such as offshoring, are no longer fit for this purpose in a world where shared prosperity and development are the only guarantors of shared security and stability. Thus, the answer is by bringing value, not volume, to the equation; by enhancing the sophistication of what nature gave in abundance to each of the world's regions. Time is of the essence, especially with the aftermath of the Great Global Recession still biting in emerging markets.

This paradigm of development is associated with high salaries policies that directly impact in increasing per capita GDP. We believe that every region on the planet possesses unique characteristics, and it is from the development of those characteristics that every nation must find a unique path of development, and that the value-enhancement is started through a deliberate act of bricolage, i.e., the construction or creation from a diverse range of available resources.

\section{Lessons of Race-to-the-Top Strategies in New Zealland, Basque Country, and Chile}

Let us consider novel lessons of this new strategic perspective from developed and emerging economies.

The impact of the milk sector in the economy of New Zealand provides pragmatic lessons of race-to-the-top strategies. NZ performs the global largest share of dairy products, and it reached in last decade the highest levels of sophisticated goods from milk, duplicating its GDP per capita. Industry's outputs are sophisticated through the intense $R \& D$ activities of the Biotech dedication of NZ's universities such as Victoria, Waikato, and Auckland. Farmers get access to improved methods of production and smart business practices. Production and processing of milk is organized through a successful model of cooperatives companies, like Fonterra, the global company owned by 13,000 farmers (Ruelas-Gossi, 2016).

In Spain, the Basque Country has enhanced its steel industry through a new strategic perspective. Basque Country had an unemployment rate of around $25 \%$ and a per capita income of approximately US $\$ 13,000$ in the 1990 s. It reached full employment and more than tripled per capita income to US $\$ 42,500$ in less than two decades. Local leaders managed this by enhancing value - not reducing it. More than $50 \%$ of the region's workers are employed in the industrial sector, mainly steel. The price of steel is set in international markets and is subject to high cyclical variations. But the Basque Country focused on product and process innovations, which minimized exposure to price volatility. It was able to increase the value of its exports, even as labor costs rose. The country achieved this 
through supporting world-class research and innovation. To ensure effective knowledge transfer, private sector participants join the boards of R\&D think-tanks like Tecnalia, Ikerlan, that had reached a global strong presence (Ruelas-Gossi, 2016).

In Chile- to cope also with the cyclical variations of copperthey made an innovative leap into the healthcare sector, that represents a clear departure of the commodity trap. A metal traditionally known as one of the best conductors of electricity, has begun to shine in the healthcare field.

They launched a joint public- and private-sector (copper firms, $\mathrm{R} \& \mathrm{D}$ centers at universities) initiative aiming to enhance the development of the country's mining sector, a project utilizing copper as an antibacterial agent at the Hospital of Calama in Chile's Second Region. It involves applying copper and copper alloys to medical devices that require repeated touching or handling. Such devices include serum holders; pencils for inputting data on computer screens; meal tables for patients; levers that regulate beds and bed arms, and chairs for hospital visitors. In each case, the goal is to combat the spread of infections inside the hospital. The Environmental Protection Agency in the US has recognized copper as the leading anti-bacterial metal in the world, opening enormous uses and possibilities for copper in hospitals. Chile holds the largest GDP per capita in Latin America.

\section{Patterns of This Race-to-the-Top Paradigm}

I have identified 5 patterns of this race-to-the-top paradigm:

Focusing on the high-value of their market segments. According with the international entrepreneurship field, the creation of future goods and services arises from the exploration of opportunities across national borders. In the new paradigm, each company explores these opportunities for new products and services in their market segments. Through their networks with organizations and government institutions the firm can generate outputs with high value for their segments. For instance, like New Zealand's Tatua and Westland, smaller cooperatives related to Fonterra, that develop specialized, unique, and niche products, as a result of private-public competitiveness policy toward enhancing the milk sector or like the Basques, that rather than trying to make the cheapest steel in the world, they enhanced value. For instance, they don't produce steel for making doors but for sophisticated products such as spacecraft.

Deepening the science behind the business. The activities of $\mathrm{R} \& \mathrm{D}$ are expensive for the firms, especially in Latin American emerging economies (Ruelas-Gossi, 2004). That is why the Inter-American Development Bank (IDB) has stimulated an international policy to create research centers in countries such as Chile and Colombia. These centers can depend on the government or universities and they generate knowledge with high impact in the production of technological innovations. For example, like the Chilean R\&D Centers identified copper's antibacterial qualities and its ability to limit the spread of pathogenic microorganisms, or New Zealand tech initiative that developed biofuel by processing a waste stream from casein (main protein milk) manufacture into bio-ethanol, and anti-cancer therapies.

Expanding into more products/industries. The knowledge based view (KBV) argues that knowledge is the most important resource for a firm (Wernerfelt, 1984). The development and strategic use of knowledge enables companies to build a competitive advantage through which they can create value and earn superior returns (Barney, 1991; Grant, 1996). When knowledge is protected through patents, firms can explore new uses for this knowledge as a base for new products and then develop new industries. For instance, the use of copper in food processing and at industrial scale like copper-lined air conditioning filters, or even as antimicrobial agent in socks, towels and underwear, and also it will extend its use in the home, in bathrooms and kitchens. Or the New Zealand milk expanding into healthcare goods: like breeding cows that produces low-fat milk, high in omega-3 oils and polyunsaturated fat, organic dairy ingredients, complex lipids from milk, infant formula from goat milk and the world's first long-life goat milk. The Basques have mixed the steel with technology in a very large variety of machinery applications and finished goods such as elevators, escalators, ramps, walkways, etc.

Orchestrating public-private cooperation through robust policies development, In the orchestration, the companies create value by generating innovative combinations of resources that satisfy client needs. The orchestration integrates different nodes that are the individuals, the business units, the companies or government institutions that control the relevant resources and make them available to fill the existing gap in the market (Ruelas-Gossi \& Sull, 2006). For example, like the Basques, who after signing the third stage of the Basque Economic Agreement in 1981, the regional government brought together public and private sector players to introduce new competitiveness policies, creating a web of nonprofit institutions linked to public and private universities, or the private-public competitiveness policy toward enhancing the milk sector of New Zealand's exports, rooted in the orchestration of multiple factors: farmers, non-profit organizations, and government; contributing with the ongoing application of innovative technologies, on-farm productivity, new product development, advanced education system, and a sophisticated infrastructure; and

Sourcing ideas-through FDI-globally. Specific knowledge is key to the development of innovations in organizations. The creation and protection of new specific knowledge allows companies to create long-term benefits, improve competitive 
positioning and significantly improve corporate performance. In Latin America, the investment in R\&D is low and the universities play a key role in the generation of specific knowledge and innovations they can capture national and international financial resources for exploring ideas and then transforming them in innovations. For example, the intensity of the interaction between the University of California System with New Zealand through entities like UCEAP (University of California Education Abroad Program). This academic interaction has allowed the transformation of ideas in products with high value around the dairy $\mathrm{NZ}$ industry.

Here some recent examples from Latin America that are trying to escape from the commodity trap like Ecuadorian Pakari, the Chilean Codelco innovative applications (Wharton, 2008), the salmon skin shoes, with a growing success in both the US and Western Europe or the colorful Colombian flowers from the field to your table.

In a nutshell, the right policy question is not whether to enter an existing global value chain, but how to create its own original value path, with the ultimate goal of sophistication and enhanced value.

\section{Conclusion}

In general terms, organizations and governments in emerging economies have taken the easy way when they have prioritized "doing" instead of "thinking," while the gap between rich and poor keeps widening (Prahalad \& Hammond, 2002). Latin American emerging economies have based their development on the exploitation of natural resources in the last decades and they have also adopted policies for the promotion of FDI in their countries by incentives of low cost of labor and including better taxes conditions. This situation has generated a focus in emerging economies on producing goods and services that others are creating.

This short article proposes a novel approach to business strategies and public policies toward bridging the gap between developed and emerging economies. A race-to-the-top paradigm, based on the sophistication (value enhancement) of resources that are distinctively present across every region in the planet. This approach introduces a virtuous circle by leveraging a country's natural advantage through a value-enhancing sophistication strategy toward a self-perpetuating virtuous circle of development. Leveraging those resources may potentially attain high levels of sophistication, and accordingly, of higher per capita income/value for the region/nation. A development strategy based on value-enhancement is superior to a strategy based on mere cost reduction. The examples from New Zealand, the Basque Country (Spain), and Chile can help not only managers but also policymakers in emerging economies rethink their foreign investment policies in promotion.

\section{References}

Barney, J. 1991. Firm Resources and Sustained Competitive Advantage. Journal of Management, 17(1): 99-120.

Ghemawat, P., \& Altman, S. 2016. Emerging Economies: Differences and Distances. AlB Insights, 16(4): 7-9.

Grant, R. 1996. Toward a Knowledge-Based Theory of the Firm. Strategic Management Journal, 17(Special issue): 109-122.

Kay, E., \& Lewenstein, W. 2013. The Problem with the "Poverty Premium". Harvard Business Review, 91 (4): $21-23$.

Muniz, F. 2014. Francisca Apparcel: ES salmon leather y chilote house shoes. http://www.cityen.cl/francisca-apparcel-es-salmon-leathery-chilote-house-shoes/.

Prahalad, C., \& Hammond, A. 2002. Serving the World's Poor, Profitably. Harvard Business Review, 80(9): 4-11.

Ruelas-Gossi, A. 2004. El paradigma de la T grande: innovar en mercados emergentes. Harvard Business Review AL, 63-71.

Ruelas-Gossi, A. 2010a. Mexico's Maquila Syndrome. http://hbr. org/2010/10/mexicos-maquiladora-syndrome.

Ruelas-Gossi, A. 2010b. How Colombia Can Turn Its Economy Around. https://hbr.org/2010/12/how-colombia-can-turn.

Ruelas-Gossi, A. 2013. The Four Obsessions of Management. Harvard Deusto Business Review, 52-60.

Ruelas-Gossi, A. 2016. Why Mexico's economy doesn't depend on the next U.S. president. Harvard Business Review, November 9: https:// hbr.org/2016/11/why-mexicos-economy-doesnt-depend-on-thenext-u-s-president.

Ruelas-Gossi, A., \& Sull, D. 2006. Orquestación estratégica: La clave para la agilidad en el escenario global. Harvard Business Review, 84(11): 43-52.

Wharton. 2008. In Chile, Copper makes an innovative leap into healthcare sector. http://knowledge.wharton.upenn.edu/article/in-chilecopper-makes-an-innovative-leap-into-the-healthcare-sector/.

Wernerfelt, B. 1984. A Resource- Based View of the Firm. Strategic Management Journal, 5(2): 171-180.

Alejandro Ruelas-Gossi (aruelas-gossi@bus.miami.edu) is a professor of strategy at the University of Miami School of Business Administration and a visiting research professor at New York University Stern School of Business. He is a consultant for several Fortune 500 companies such as Sony, Motorola, Microsoft, Bristol-Myers, IBM, Philips, Caterpillar, Cemex, Baxter, Ernst \& Young, Aon, Techint, AT\&T and Abbott. He was founder and GM of the "Think-tank Orkestra" in the Basque Institute of Competitiveness, Spain. 